\title{
Synthesis and Structural Evaluation of 5-Methyl-6-acetyl Substituted Indole and Gramine
}

\section{Lovel Kukuljan, Krištof Kranjc* and Franc Perdih*}

\author{
Faculty of Chemistry and Chemical Technology, University of Ljubljana, Večna pot 113, SI-1000 Ljubljana, Slovenia \\ *Corresponding author: E-mail: franc.perdih@fkkt.uni-lj.si; kristof.kranjc@fkkt.uni-lj.si
}

Received: 13-09-2016

\begin{abstract}
The synthesis and crystal structures of 1-(5-methyl- $1 H$-indol-6-yl)ethan-1-one $(7), \mathrm{C}_{11} \mathrm{H}_{11} \mathrm{NO}$, and 1-\{3-[(dimethylamino)methyl]-5-methyl-1 $\mathrm{H}$-indol-6-yl\}ethan-1-one (8), $\mathrm{C}_{14} \mathrm{H}_{18} \mathrm{~N}_{2} \mathrm{O}$, are reported. The synthesis is based on the Diels-Alder cycloaddition of a substituted $2 \mathrm{H}$-pyran-2-one derivative, followed by an acid-catalyzed cyclization and concomitant deprotection (the last two steps were carried out as a one-pot domino process) yielding substituted indole $\mathbf{7}$, which was further derivatized via Mannich reaction to the gramine derivative 8. Both structures $\mathbf{7}$ and $\mathbf{8}$ were determined on the basis of IR, ${ }^{1} \mathrm{H}$ NMR and mass spectroscopy, as well as by the elemental analysis and melting point determination. According to the single-crystal X-Ray diffraction analysis, the structure $\mathbf{7}$ has a single unique molecule in the asymmetric unit whereas the structure $\mathbf{8}$ contains four unique molecules in the asymmetric unit. Molecules $\mathbf{7}$ are linked via $\mathrm{N}-\mathrm{H} \cdots \mathrm{O}$ hydrogen bonds between the secondary amine group and carbonyl moiety of the acetyl group of adjacent molecules, whereas molecules $\mathbf{8}$ are linked via $\mathrm{N}-\mathrm{H} \cdots \mathrm{N}$ hydrogen bonds between the secondary and tertiary amine groups of adjacent molecules. Both structures are further stabilized by weak $\mathrm{C}-\mathrm{H} \cdots \mathrm{O}, \mathrm{C}-\mathrm{H} \cdots \pi$ and $\pi \cdots \pi$ interactions.
\end{abstract}

Keywords: Indoles, Gramines, Crystal structure, Hydrogen bonds, $\mathrm{C}-\mathrm{H} \cdots \pi$ interaction, $\pi \cdots \pi$ interaction

\section{Introduction}

Gramine, 3-(N,N-dimethylaminomethyl)indole, is a simple indole derivative with important functions in the plant world. The essential amino acid tryptophan and its derivatives are biosynthesized from gramine. Gramine was isolated for the first time from the giant cane (Arundo donax), has a role as an alkaloid in barley (Hordeum vulgare) and is of importance in many other plants. ${ }^{1,2}$

Furthermore, gramine represents a valuable precursor for further derivatizations towards other targets, for example for the preparation of 1,3-disubstituted $\beta$-carbolines by the reaction of gramines with $\alpha$-(alkylidenamino)nitriles in the presence of tributylphosphine ${ }^{3}$ and for the synthesis of the 2-prenyl tryptophan core of the tryprostatins $\mathrm{A}$ and $\mathrm{B} .{ }^{4}$ For the quaternary gramine derivatives it was shown that they can be used as suitable sources of the 3-methylindole fragment in various diastereoselective alkylations, as recently described by Reinfelds et $a l .{ }^{5}$ Gramine has also found utility as a part of $N$-substituted phosphines that were used as ligands in Suzuki-Miyaura coupling reactions of aryl halogenides, conducted at room temperature in a suitable ionic liquid, thus achieving in- creased yields in comparison with standard ligands containg amine groups. ${ }^{6}$

Gramine derivatives also possess various biological activites; recently it was found that a gramine derivative (i.e. $\quad N$-[(1H-indol-3-yl)(pyridin-2-yl)methyl]benzo[d] thiazol-2-amine) having a pyridine and a benzothiazole moiety in its structure selectively inhibits human enterovirus 71 (EV71), a known agent of hand, foot and mouth disease in children associated with severe neurological problems, including death; on the other hand, the parent gramine does not inhibit EV71. ${ }^{7}$

The synthetic approach used toward gramine and its derivatives is most often Mannich reaction ${ }^{8}$ of the corresponding indoles: the position 3 of the indole framework (being the most nucleophilic) attacks an intermediate formed from formaldehyde and a secondary amine. The reaction can be accelerated by the application of suitable additives, Dai et al. ${ }^{9}$ have successfully applied zinc chloride among various other options. Such synthesis generally takes place at room temperature and is finished in a relatively short time (typically $90 \mathrm{~min}$ ).

The scope of such reaction can be further broadened by the application of various aromatic aldehydes (instead 
of formaldehyde) and various heterocyclic compounds (instead of secondary amines) as demonstrated by Ke and co-workers. ${ }^{10}$ During their synthetic protocol there was no need to use any catalysts or solvents.

Analogues of gramine can be also prepared by the reaction between substituted 1,4-piperazines, $1 H$-indole and formaldehyde. With such an approach, Köksal Akkoç et al. ${ }^{11}$ were able to synthesize compounds with increased cytotoxicity against human carcinoma cells compared with the other commercially available agents, such as the standard drug 5-fluorouracil.

Herein we present a straightforward approach towards a substituted gramine based on a Diels-Alder reaction between a corresponding $2 H$-pyran-2-one (acting as a diene) and a suitable dienophile (i.e. (Z)-1-methoxybut-1-en-3-yne) yielding a cycloadduct that is in the next step transformed into the desired indole, which is further derivatized via Mannich reaction to the substituted gramine.

\section{Experimental}

\section{1. Materials and Measurements}

Melting points were determined on a micro hot stage apparatus and are uncorrected. ${ }^{1} \mathrm{H}$ NMR spectra were recorded with a Bruker Avance DPX 300 spectrometer at $29{ }^{\circ} \mathrm{C}$ and $300 \mathrm{MHz}$ using $\mathrm{Me}_{4} \mathrm{Si}$ as an internal standard. IR spectra were obtained with a Bio-Rad FTS $3000 \mathrm{MX}$ as $\mathrm{KBr}$ pellets. MS spectra were recorded with a VG-Analytical AutoSpec Q instrument. Elemental analyses $(\mathrm{C}, \mathrm{H}$, N) were performed with a Perkin Elmer 2400 Series II CHNS/O Analyzer. TLC was carried out on Fluka silicagel TLC-cards. All reagents and solvents were used as received from commercial suppliers.

Starting $N$-\{5-acetyl-2-[(Z)-2-methoxyethenyl]-4methylphenyl benzamide (5) was prepared via Diels-Alder cycloaddition of (Z)-1-methoxybut-1-en-3-yne (4) on $\mathrm{N}$-(5-acetyl-6-methyl-2-oxo-2 $\mathrm{H}$-pyran-3-yl)benzamide (3) as described previously. ${ }^{12}$ Commercially $\mathbf{4}$ is available as a 50\% methanol solution and has to be distilled under vacuum prior to use; the distillation of a mixture of $7 \mathrm{~mL}$ of commercial 4 and $5 \mathrm{~mL}$ of isopentanol at $360 \mathrm{mbar}$ starts at $45{ }^{\circ} \mathrm{C}$ : the first fraction is methanol, the second (distilling at $90{ }^{\circ} \mathrm{C}$ ) is pure $\mathbf{4}$ (a pale yellow liquid with a characteristic odour). Purified $\mathbf{4}$ has a limited shelf life even when stored in dark at $-20{ }^{\circ} \mathrm{C}$.

\section{Synthesis of 1-(5-Methyl-1H-indol-6-yl)ethan-1-one (7)} To a solution of $N$-\{5-acetyl-2-[(Z)-2-methoxyethenyl]4-methylphenyl benzamide (5) $(0.309 \mathrm{~g}, 1 \mathrm{mmol})$ in acetonitrile $(10 \mathrm{~mL})$ hydrochloric acid $(5 \%, 0.25 \mathrm{~mL})$ was added. The mixture was stirred for $18 \mathrm{~h}$ at room temperature, thereafter neutralized with $\mathrm{NaOH}(0.113 \mathrm{~g}, 2.825$ mmol dissolved in $4 \mathrm{~mL}$ of water). The resulting mixture was heated under reflux for $1 \mathrm{~h}$, cooled to room tempera- ture and extracted with EtOAc $(2 \times 20 \mathrm{~mL})$. Combined organic phases were washed with water $(3 \times 10 \mathrm{~mL})$, dried over anhydrous $\mathrm{Na}_{2} \mathrm{SO}_{4}$ and volatile components evaporated under reduced pressure yielding $0.148 \mathrm{~g}$ (86\%) of the title product 7. M.p. $139-141{ }^{\circ} \mathrm{C}$ (EtOAc). IR (KBr) 3318, 1642, 1619, 1559, 1492, 1435, 1418, $1301 \mathrm{~cm}^{-1} .{ }^{1} \mathrm{H}$ NMR $\left(300 \mathrm{MHz}, \mathrm{CDCl}_{3}\right) \delta 2.636(\mathrm{~s}, 3 \mathrm{H}$, $\mathrm{Me}), 2.639$ (s, 3H, Me), $6.50(\mathrm{~m}, 1 \mathrm{H}, 3-\mathrm{H}), 7.34(\mathrm{~m}, 1 \mathrm{H}$, 2-H), 7.47 (s, 1H, 7-H), $7.84(\mathrm{~s}, 1 \mathrm{H}, 4-\mathrm{H}), 8.38(\mathrm{~s}, 1 \mathrm{H}$, $\mathrm{NH})$. MS (ESI+) $\mathrm{m} / z 174\left(\mathrm{MH}^{+}\right)$. Anal. calcd. for $\mathrm{C}_{11} \mathrm{H}_{11} \mathrm{NO}$ : C, 76.28; H, 6.40; N, 8.09. Found: C, 76.11; $\mathrm{H}, 6.11 ; \mathrm{N}, 8.07$.

\section{Synthesis of 1-\{3-[(Dimethylamino)methyl]-5-methyl-} $1 H$-indol-6-yl $\}$ ethan-1-one (8)

To a mixture of 1-(5-methyl- $1 H$-indol-6-yl)ethan-1-one (7) $(0.285 \mathrm{~g}, 1.646 \mathrm{mmol})$ and ethanol $(6 \mathrm{~mL})$ the following were added: $60 \%$ aqueous solution of dimethylamine $\left(0.186 \mathrm{~g}, 1.5\right.$ eq.), anhydrous $\mathrm{ZnCl}_{2}(0.339 \mathrm{~g}, 1.5$ eq. $)$ and $35 \%$ aqueous solution of formaldehyde $(0.230 \mathrm{~g}, 1.5$ eq.). The resulting suspension was stirred at room temperature for $3 \mathrm{~h}$. Thereafter, aqueous $\mathrm{NaOH}(5 \%, 5 \mathrm{~mL})$ was added to the reaction mixture and undissolved material was filtered off. The undisolved material was disposed, whereas the filtrate was extracted with EtOAc $(2 \times 10$ $\mathrm{mL})$. Combined organic phases were evaporated under reduced pressure, the remaining material was treated with water $(3 \mathrm{~mL})$ and aqueous $\mathrm{HCl}$ was added $(5 \%$, $2 \mathrm{~mL}$ ). Thus precipitated unreacted indole was removed by filtration, the remaining clear filtrate was treated with aqueous $\mathrm{NaOH}(5 \%, 2 \mathrm{~mL})$ causing new precipitate to appear. The resulting suspension was extracted with $\mathrm{Et}_{2} \mathrm{O}$ $(4 \times 5 \mathrm{~mL})$ and combined organic phases were dried over anhydrous $\mathrm{MgSO}_{4}$. The solvent was left to evaporate and the yellow crystals formed were collected and re-crystallized from EtOAc yielding $0.136 \mathrm{~g} \mathrm{(36 \% )}$ of the title product 8. M.p. $126-128{ }^{\circ} \mathrm{C}$ (EtOAc). IR (KBr) 3085, 2789, 1669, 1620, 1467, 1449, 1356, 1241, $1203 \mathrm{~cm}^{-1} .{ }^{1} \mathrm{H}$ NMR (300 MHz, $\left.\mathrm{CDCl}_{3}\right) \delta 2.29\left(\mathrm{~s}, 6 \mathrm{H}, \mathrm{NMe}_{2}\right), 2.59(\mathrm{~s}$, $3 \mathrm{H}, \mathrm{Me}), 2.62(\mathrm{~s}, 3 \mathrm{H}, \mathrm{Me}), 3.61\left(\mathrm{~s}, 2 \mathrm{H}, \mathrm{CH}_{2}\right), 7.22$ (m, 1H, 2-H), 7.49 (s, 1H, 7-H), 7.73 (s, 1H, 4-H), 8.88 (s, $1 \mathrm{H}, \mathrm{NH})$. MS (ESI+) $\mathrm{m} / z 231\left(\mathrm{MH}^{+}\right)$. Anal. calcd. for $\mathrm{C}_{14} \mathrm{H}_{18} \mathrm{~N}_{2} \mathrm{O}$ : C, 73.01; H, 7.88; N, 12.16. Found: C, 73.16; $\mathrm{H}, 8.18 ; \mathrm{N}, 12.21$.

\section{2. Crystallography}

Single-crystal X-ray diffraction data were collected at room temperature on an Agilent Technologies SuperNova Dual diffractometer using $\mathrm{Cu}-\mathrm{K} \alpha$ radiation $(\lambda=$ $1.54184 \AA$ ). The data were processed by CrysAlis Pro. ${ }^{13}$ Structures were solved by direct methods implemented in Superflip ${ }^{14}$ and refined by a full-matrix least-squares procedure based on $F^{2}$ using SHELX2014. ${ }^{15}$ All non-hydrogen atoms were refined anisotropically. Hydrogen atoms were readily located in a difference Fourier maps and were 
Table 1. Crystal data and refinement parameters for the compounds $\mathbf{7}$ and $\mathbf{8}$.

\begin{tabular}{|c|c|c|}
\hline Compound & 7 & $\mathbf{8}$ \\
\hline $\mathrm{CCDC}$ & 1503990 & 1503991 \\
\hline Molecular formula & $\mathrm{C}_{11} \mathrm{H}_{11} \mathrm{NO}$ & $\mathrm{C}_{14} \mathrm{H}_{18} \mathrm{~N}_{2} \mathrm{O}$ \\
\hline Molecular weight & 173.21 & 230.30 \\
\hline Crystal system & Orthorhombic & Monoclinic \\
\hline Space group & $P$ с a 2 & $P 2_{1}$ \\
\hline Temperature $(\mathrm{K})$ & $293(2)$ & 293(2) \\
\hline$a(\AA)$ & $18.2632(7)$ & $9.0846(2)$ \\
\hline$b(\AA)$ & $5.2027(2)$ & $21.4971(2)$ \\
\hline$c(\AA)$ & $9.4496(3)$ & $13.0190(2)$ \\
\hline$\alpha\left(^{\circ}\right)$ & 90 & 90 \\
\hline$\beta\left(^{\circ}\right)$ & 90 & $90.106(2)$ \\
\hline$\gamma\left({ }^{\circ}\right)$ & 90 & 90 \\
\hline$V\left(\AA^{3}\right)$ & $897.88(6)$ & $2542.51(7)$ \\
\hline Z & 4 & 8 \\
\hline$D_{\text {all }}\left(\mathrm{g} \mathrm{cm}^{-3}\right)$ & 1.281 & 1.203 \\
\hline Absorption coefficient $\left(\mathrm{mm}^{-1}\right)$ & 0.656 & 0.604 \\
\hline$F(000)$ & 368 & 992 \\
\hline Crystal dimensions (mm) & $0.30 \times 0.20 \times 0.03$ & $0.60 \times 0.40 \times 0.08$ \\
\hline Flack parameter & $0.1(2)$ & $0.30(10)$ \\
\hline Reflections collected & 1994 & 49717 \\
\hline Independent reflections & $1280\left[R_{\mathrm{int}}=0.0199\right]$ & $9657\left[R_{\mathrm{int}}=0.0461\right]$ \\
\hline Data / restraints / parameters & $1280 / 1 / 121$ & $9657 / 1 / 630$ \\
\hline$R_{1}, w R_{2}[I>2 \sigma(I)]^{a}$ & $0.0320,0.0831$ & $0.0467,0.1403$ \\
\hline$R_{1}, w R_{2}\left(\right.$ all data) ${ }^{b}$ & $0.0361,0.0885$ & $0.0491,0.1431$ \\
\hline Goodness of fit on $F^{2}, S^{c}$ & 1.142 & 1.047 \\
\hline Extinction coefficient & $0.0110(16)$ & $0.0038(4)$ \\
\hline Largest diff. peak and hole $\left(\mathrm{e} \AA^{-3}\right)$ & 0.124 and -0.096 & 0.265 and -0.155 \\
\hline
\end{tabular}

${ }^{a} R=\sum \| F_{\mathrm{o}}|-| F_{\mathrm{c}}\left|/ \sum\right| F_{\mathrm{o}} \mid \cdot{ }^{b} w R_{2}=\left\{\sum\left[w\left(F_{\mathrm{o}}{ }^{2}-F_{\mathrm{c}}{ }^{2}\right)^{2}\right] / \sum\left[w\left(F_{\mathrm{o}}{ }^{2}\right)^{2}\right]\right\}^{1 / 2} \cdot{ }^{c} S=\left\{\sum\left[\left(F_{\mathrm{o}}{ }^{2}-F_{\mathrm{c}}{ }^{2}\right)^{2}\right] /(n / p)\right\}^{1 / 2}$ where $n$ is the number of reflections and $p$ is the total number of parameters refined.

Table 2. Hydrogen bond and $\mathrm{CH} \cdots \pi$ geometry of $\mathbf{7}$ and $\mathbf{8}\left(\AA\right.$ and $\left.^{\circ}\right)$.

\begin{tabular}{|c|c|c|c|c|c|}
\hline D-H $\cdots A$ & D-H $(\AA)$ & $\mathbf{H} \cdots \mathbf{A}(\AA)$ & $\mathbf{D} \cdots \mathbf{A}(\AA)$ & D-H $\cdots A\left(\left(^{\circ}\right)\right.$ & Symmetry code \\
\hline \multicolumn{6}{|l|}{7} \\
\hline N1-H1O1 & 0.86 & 2.04 & $2.893(3)$ & 174.2 & $-x+1 / 2, y+1, z+1 / 2$ \\
\hline C11-H11C…O1 & 0.96 & 2.56 & $3.513(4)$ & 171.2 & $x, y+1, z$ \\
\hline C9-H9A $\cdots C g 2$ & 0.96 & 2.90 & $3.688(3)$ & 140 & $x, y-1, z$ \\
\hline \multicolumn{6}{|l|}{8} \\
\hline $\mathrm{N} 1-\mathrm{H} 1 \cdots \mathrm{N} 4$ & 0.86 & 2.10 & $2.936(4)$ & 165.1 & $x-1, y, z$ \\
\hline $\mathrm{N} 3-\mathrm{H} 3 \cdots \mathrm{N} 2$ & 0.86 & 2.15 & $2.983(4)$ & 163.7 & $x, y, z$ \\
\hline N5-H5 № 8 & 0.86 & 2.11 & $2.951(4)$ & 164.6 & $x, y, z$ \\
\hline N7-H7A ‥N6 & 0.86 & 2.14 & $2.978(4)$ & 164.4 & $x+1, y, z$ \\
\hline C38-H38A ‥O1 & 0.96 & 2.58 & $3.392(5)$ & 142.6 & $-x, y-1 / 2,-z+1$ \\
\hline $\mathrm{C} 42-\mathrm{H} 42 \mathrm{~A} \cdots \mathrm{O} 4$ & 0.96 & 2.51 & $3.407(5)$ & 154.8 & $-x+1, y+1 / 2,-z+1$ \\
\hline C56-H56B … & 0.96 & 2.51 & $3.358(6)$ & 146.6 & $-x+1, y-1 / 2,-z+1$ \\
\hline $\mathrm{C} 1-\mathrm{H} 1 \mathrm{~A} \cdots C g 5$ & 0.93 & 2.90 & $3.743(4)$ & 151 & $x-1, y, z$ \\
\hline $\mathrm{C} 15-\mathrm{H} 15 \cdots C g 2$ & 0.93 & 2.88 & $3.715(4)$ & 150 & $x, y, z$ \\
\hline $\mathrm{C} 29-\mathrm{H} 29 \cdots C g 11$ & 0.93 & 2.81 & $3.668(4)$ & 154 & $x, y, z$ \\
\hline $\mathrm{C} 43-\mathrm{H} 43 \cdots C g 8$ & 0.93 & 2.82 & $3.680(4)$ & 154 & $x+1, y, z$ \\
\hline
\end{tabular}

$C g 2, C g 5, C g 8$ and $C g 11$ are $\mathrm{C} 3-\mathrm{C} 8, \mathrm{C} 17-\mathrm{C} 22, \mathrm{C} 31-\mathrm{C} 36$ and $\mathrm{C} 45-\mathrm{C} 50$ ring centroids.

subsequently treated as riding atoms in geometrically idealized positions, with $\mathrm{C}-\mathrm{H}=0.93$ (aromatic), 0.97 (methylene) or $0.96 \AA\left(\mathrm{CH}_{3}\right), \mathrm{N}-\mathrm{H}=0.86 \AA$ and with $U_{\text {iso }}(\mathrm{H})=k$ -
$U_{\text {eq }}(\mathrm{C}$ or $\mathrm{N})$, where $k=1.5$ for methyl groups, which were permitted to rotate but not to tilt, and 1.2 for all other $\mathrm{H}$ atoms. Crystallographic data are listed in Table 1. 


\section{Results and Discussion}

\section{1. Synthesis}

The synthetic approach presented herein is based on our previous experience with Diels-Alder reactions of $2 \mathrm{H}$-pyran-2-one derivatives (used as dienes) with various dienophiles. ${ }^{16-21}$ Here we applied (Z)-1-methoxybut-1-en3 -yne (4) as the dienophile cycloadding on $2 \mathrm{H}$-pyran-2one derivative $\mathbf{3}$ yielding a crucial intermediate $\mathbf{5}$, a substituted $N$-\{2-[(Z)-2-methoxyethenyl]phenyl\}benzamide (Scheme 1). This intermediate $\mathbf{5}$ has a strategically positioned methoxy group bound to the ethenyl fragment being in an ortho position to the benzamido group, therefore enabling a straightforward cyclization towards the indole ring (i.e. 6) already under mildly acidic conditions, as described previously. ${ }^{12}$ However, an indole 6 obtained in such a way still contains an $\mathrm{N}$-benzoyl protection group that needs to be removed to yield the indole 7 . One possibility to achieve this could be the application of aqueous $\mathrm{NaOH}$ in a mixture of water and acetonitrile with gentle heating. ${ }^{22}$

On the other hand, our strategy was to combine both steps described above, i.e. the cyclization $(\mathbf{5} \rightarrow \mathbf{6})$ and the removal of the $N$-benzoyl group $(\mathbf{6} \rightarrow 7)$ into a single step. Even though the first step needs acidic conditions and the second takes place in an alkaline solution, with a suitable choice of reaction parameters we were able to implement both transformations as a one-pot domino procedure. Primary cycloadduct $\mathbf{5}, \quad N-\{2-[(Z)-2$-methoxyethenyl $]$ phenyl \}benzamide derivative, was thus dissolved in acetonitrile, aqueous $\mathrm{HCl}$ was added and the mixture was stirred at room temperatue; thereafter enough aqueous $\mathrm{NaOH}$ was added to neutralize the excess $\mathrm{HCl}$ and to increase the $\mathrm{pH}$ to an appropriately alkaline value (pH approx. 10) for the deprotection to occur (upon gentle hea- ting). Such approach to 7 shortens the synthetic pathway towards 7 and increases its final yield $(86 \%$ yield after a one-pot procedure $\mathbf{5} \rightarrow \mathbf{7}$ vs. $71 \%$ combined yield over two separate steps).

Resonances in the ${ }^{1} \mathrm{H}$ NMR spectrum of the indole 7 are in agreement with those expected: both methyl groups were observed as singlets (at $\delta 2.636$ and 2.639 $\mathrm{ppm}$ ), together with the four aromatic protons (in the range $\delta 6.50-7.84 \mathrm{ppm}$ ) and the amino proton as a singlet at $\delta 8.38 \mathrm{ppm}$. In the IR spectrum of $\mathbf{7}$ bands correspond to the $\mathrm{NH}$ group at $3318 \mathrm{~cm}^{-1}$ and carbonyl group at 1642 $\mathrm{cm}^{-1}$.

The starting indole 7 was thereafter derivatized under standard Mannich reaction conditions (with formaldehyde and dimethylamine in ethanol as the solvent and with zinc chloride as the additive) $)^{8}$ to form the 6-acetyl-5methylgramine derivative $\mathbf{8}$.

For the gramine derivative 8 in the ${ }^{1} \mathrm{H}$ NMR spectrum appropriate signals were observed: all four methyl groups as singlets (dimethylamino group at $\delta 2.29 \mathrm{ppm}$ and the remaining two methyl groups at $\delta 2.59$ and 2.62 $\mathrm{ppm}$ ), the methylene group as a singlet at $\delta 3.61 \mathrm{ppm}$, the three aromatic protons (in the range $\delta 7.22-7.73 \mathrm{ppm}$ ) and the amino proton as a singlet at $\delta 8.88 \mathrm{ppm}$. In the IR spectrum of $\mathbf{8}$ bands correspond to the NH group at 3085 $\mathrm{cm}^{-1}$ and carbonyl group at $1669 \mathrm{~cm}^{-1}$.

$2 \mathrm{H}$-Pyran-2-one derivatives $\mathbf{3}$, necessary for this synthetic approach, can be straightforwardly accessed via a one-pot synthesis starting from the simple commercially available precursors: a carbonyl compound $\mathbf{1}$ containing an activated $\mathrm{CH}_{2}$ group (acetylacetone), a $\mathrm{C}_{1}$-synthon such as $N, N$-dimethylformamide dimethyl acetal (DMFDMA) and hippuric acid (2) as an $\mathrm{N}$-acylglycine derivative as previously described by Kepe and Kočevar. ${ }^{23-25}$ The synthesis takes place under heating (approx. $90{ }^{\circ} \mathrm{C}$ ) in

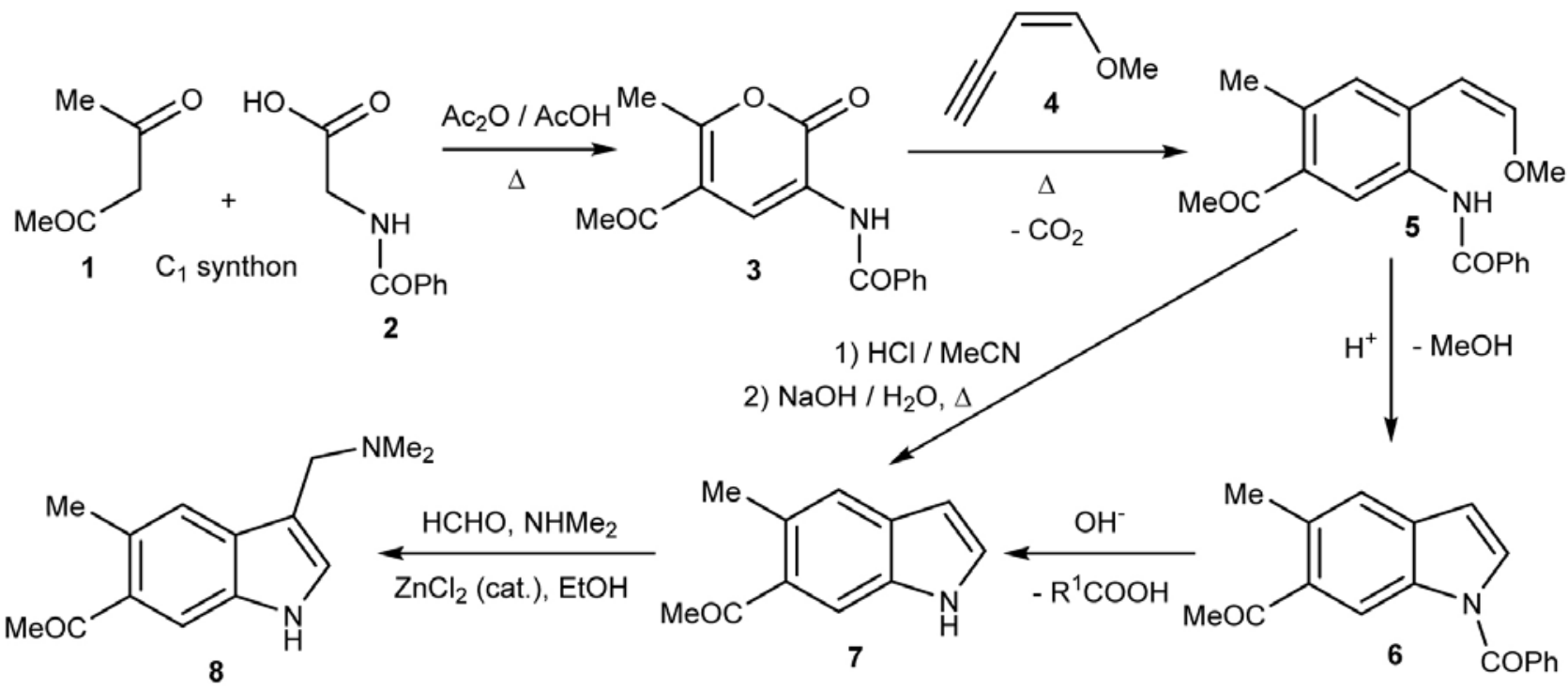

Scheme 1. Reaction sequence leading to the indole $\mathbf{7}$ and gramine $\mathbf{8}$. 
acetic anhydride (or in a mixture with acetic acid) as the solvent yielding desired substitued 3-benzoylamino- $2 \mathrm{H}$ pyran-2-ones $\mathbf{3}$.

\section{2. Crystal Structures}

The structure of 1-(5-methyl- $1 H$-indol-6-yl)ethan1-one, 7, has a single unique molecule in the asymmetric unit (Figure 1) whereas the structure of 1-\{3-[(dimethylamino)methyl]-5-methyl-1H-indol-6-yl $\}$ ethan-1-one, 8 , contains four unique molecules in the asymmetric unit (Figure 2). All the bond lengths of compounds $\mathbf{7}$ and $\mathbf{8}$ are within normal ranges. ${ }^{26}$

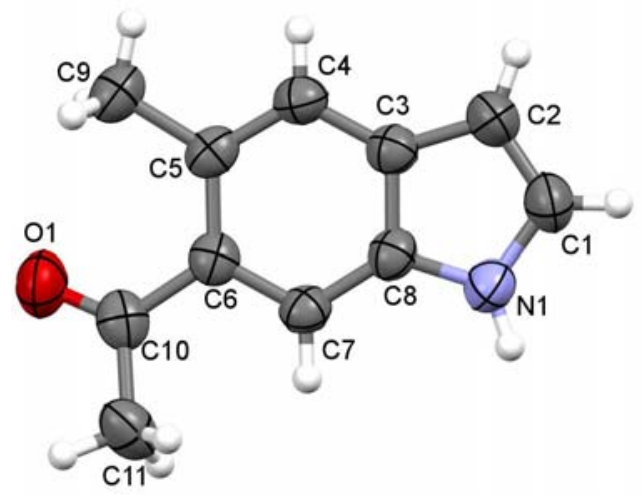

Figure 1. Molecular structure and atom numbering scheme for 7 . Probability ellipsoids are drawn at the $50 \%$ level.
In both compounds $\mathbf{7}$ and $\mathbf{8}$ the central indole ring is planar. The maximum deviation from the mean plane described by the ring atoms is $+0.014(2)$ and $-0.014(2) \AA$ for the $\mathrm{C} 8$ and $\mathrm{C} 6$ atoms in 7 and in the range +0.019 (4) to -0.019 (3) $\AA$ for four unique molecules in $\mathbf{8}$. These values are similar to those observed in the analogous series of benzotriazoles. ${ }^{27}$ The mean plane through the methylcarbonyl group $(\mathrm{C} 6 / \mathrm{C} 10 / \mathrm{O} 1 / \mathrm{C} 11)$ in 7 is inclined to the indole ring by $13.60(15)^{\circ}$ while these angles in four unique molecules of $\mathbf{8}$ are $35.8(2)^{\circ}, 36.3(2)^{\circ}, 28.6(2)^{\circ}$ and $32.59(19)^{\circ}$. Such angles in [1-methyl-2-(4-methylphenyl)- $1 H$-indole-4,6-diyl]bis(phenylmethanone) are 22.46 and $32.54^{\circ},{ }^{28}$ while in $N$ - $\{2$-[6-benzoyl-5-methyl-1(methylsulfonyl)-1H-indol-2-yl]-4-methylphenyl $\}$ methanesulfonamide this angle is much larger being $48.53^{\circ} .{ }^{29}$ The dimethylamino group in $\mathbf{8}$ is just out of the plane of its attached indole ring as indicated by the C1-C2-C9-N2, C15-C16-C23-N4, C29-C30-C37-N6 and C43-C44-C51-N8 torsion angles of four crystallographically independent molecules in the range $95.0(4)-96.9(4)^{\circ}$. The indole ring is conformationally rigid, but the dimethylamino part of the molecule has conformational variation as seen from the different torsion angles of crystallographically independent molecules in the crystal structure. In $N, N$-dimethyl- $1 H$-indole-3-methanamine, ${ }^{30} 1$-[1-(5-bromo- $1 H$-indol-3-yl)ethyl]azepan2-one monohydrate, ${ }^{31}[1-($ di-t-butylphosphino)- $1 H$-indol3 -yl]-N,N,N-trimethylmethanaminium iodide ${ }^{32}$ and $N$-[(5bromo- $1 H$-indol-3-yl)methyl]- $N, N$-dimethylammonium

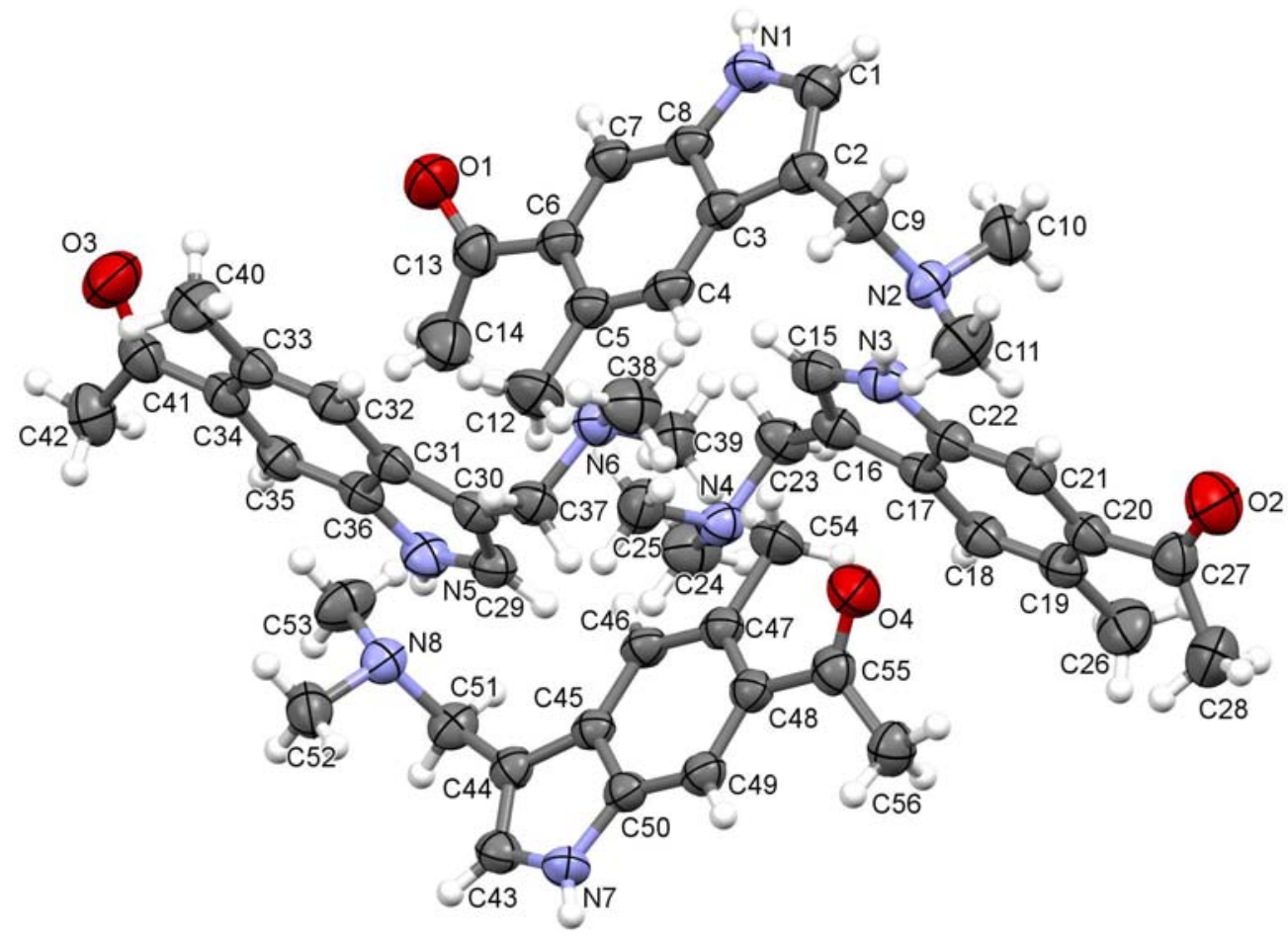

Figure 2. View of unique molecules in the asymmetric unit of $\mathbf{8}$ with the atom numbering scheme. Probability ellipsoids are drawn at the $50 \%$ level. 
nitrate $e^{33}$ equivalent torsion angles were found to be similar, with values between $92.42^{\circ}$ and $103.70^{\circ}$.

In the crystal structure molecules of 7 are linked via $\mathrm{N} 1-\mathrm{H} 1 \cdots \mathrm{O} 1(-x+1 / 2, y+1, z+1 / 2)$ hydrogen bonding between the NH group of one molecule and carbonyl oxygen of the acetyl moiety of the adjacent molecule into an infinite zig-zag chain generating the graph set motif $\mathrm{C}(7)^{34}$ (Table 2, Figure 3). These chains are cross-linked into sheets by weak $\mathrm{C} 11-\mathrm{H} 11 \mathrm{C} \cdots \mathrm{O} 1(x, y+1, z)$ hydrogen bonding between the hydrogen atom of the acetyl moiety of one molecule and carbonyl oxygen of the other molecule generating the graph set motif $\mathrm{C}(4)$. Furthermore, this $2 \mathrm{D}$ structure in 7 is stabilized by additional $\pi \cdots \pi$ interactions between the five membered pyrrole ring N1/C1-C3/C8 (centroid $C g 1$ ) and the six membered C3-C8 ring (centroid $C g 2$ ) of the other molecule, with a $C g 1 \cdots C g 2(x, y+1, z)$ centroid-to-centroid distance of 4.3536(16) $\AA$, a dihedral angle between the rings of $0.91(14)^{\circ}$, a perpendicular distance from the centroid $C g 1$ to the plane of the other ring of 3.5530(12) $\AA$ and the angle between the intercentroid vector and the normal to the second ring of $35.30^{\circ}$ (Figure 4). According to Janiak, ${ }^{35}$ this interaction can be regarded as medium-toweak, since strong interactions exhibit rather short centroid-to-centroid contacts $(C g \cdots \mathrm{Cg}<3.8 \AA)$, small slip angles $\left(<25^{\circ}\right)$ and small vertical displacements $(<1.5 \AA)$, which translate into a sizeable overlap of the aromatic planes. In comparison, medium-to-weak interactions exhibit rather long centroid-to-centroid distances $(>4.0 \AA)$ together with large slip angles $\left(>30^{\circ}\right)$ and large vertical displacements $(>2.0 \AA) .{ }^{35-37}$ Additional weak C-H $\cdots \pi$ interactions between $\mathrm{C} 9-\mathrm{H} 9 \mathrm{~A} \cdots C g 2(x, y-1, z)$ with hydrogen-to-centroid distance $3.688(3) \AA$ also stabilize the structure.

In the crystal structure $\mathbf{8}$ four unique molecules are linked via $\mathrm{N}-\mathrm{H} \cdots \mathrm{N}$ hydrogen bonding between the indole $\mathrm{NH}$ group of one molecule and the tertiary nitrogen atom of the dimethylamino group of the adjacent molecule into infinite zig-zag chains generating the graph set motif $\mathrm{C}(6)$. In each zig-zag chain two out of four unique molecules are involved. Chains are stabilized by weak $\mathrm{C}-\mathrm{H} \cdots \pi$ interactions between the $\mathrm{CH}$ group of the pyrrole moiety

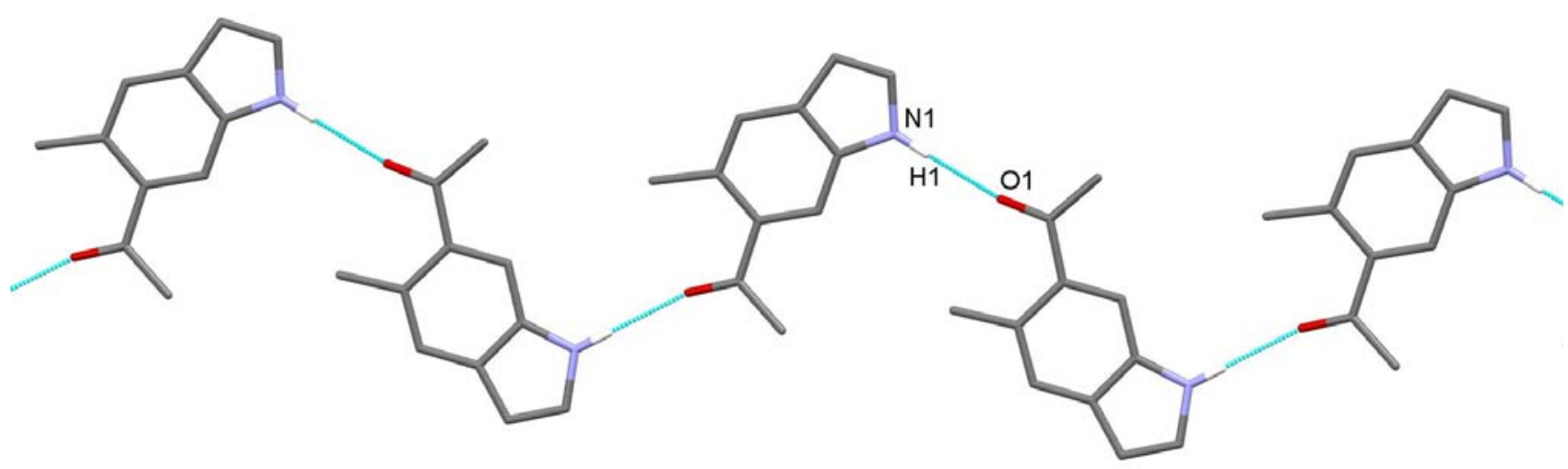

Figure 3. Zig-zag chain formation via $\mathrm{N} 1-\mathrm{H} 1 \cdots \mathrm{O} 1$ hydrogen bonding with graph set motif $\mathrm{C}(7)$ in 7 . Hydrogen atoms not involved in the motif shown have been omitted for clarity.

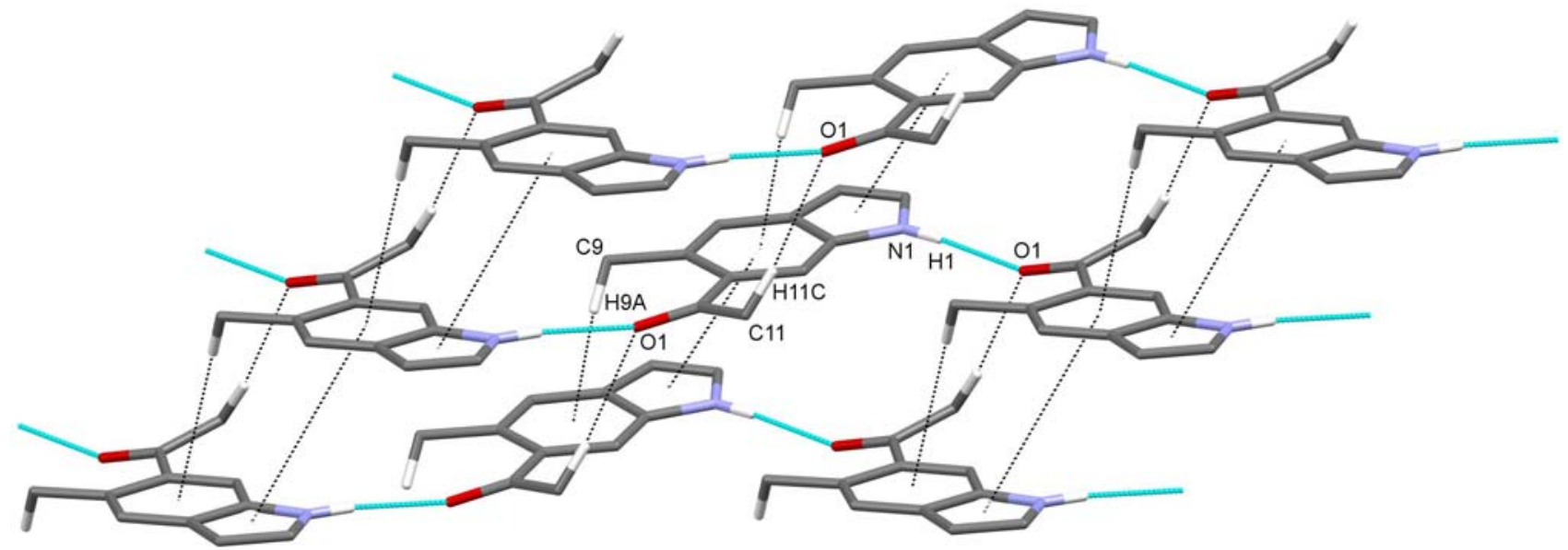

Figure 4. Sheet formation in 7 generated by $\mathrm{N} 1-\mathrm{H} 1 \cdots \mathrm{O} 1$ hydrogen bonding (blue dashed lines) and weak $\mathrm{C} 11-\mathrm{H} 11 \mathrm{C} \cdots \mathrm{O} 1, \mathrm{C} 9-\mathrm{H} 9 \mathrm{~A} \cdots \pi$ and $\pi \cdots \pi$ interactions (dashed black lines). Hydrogen atoms not involved in the motif shown have been omitted for clarity. 


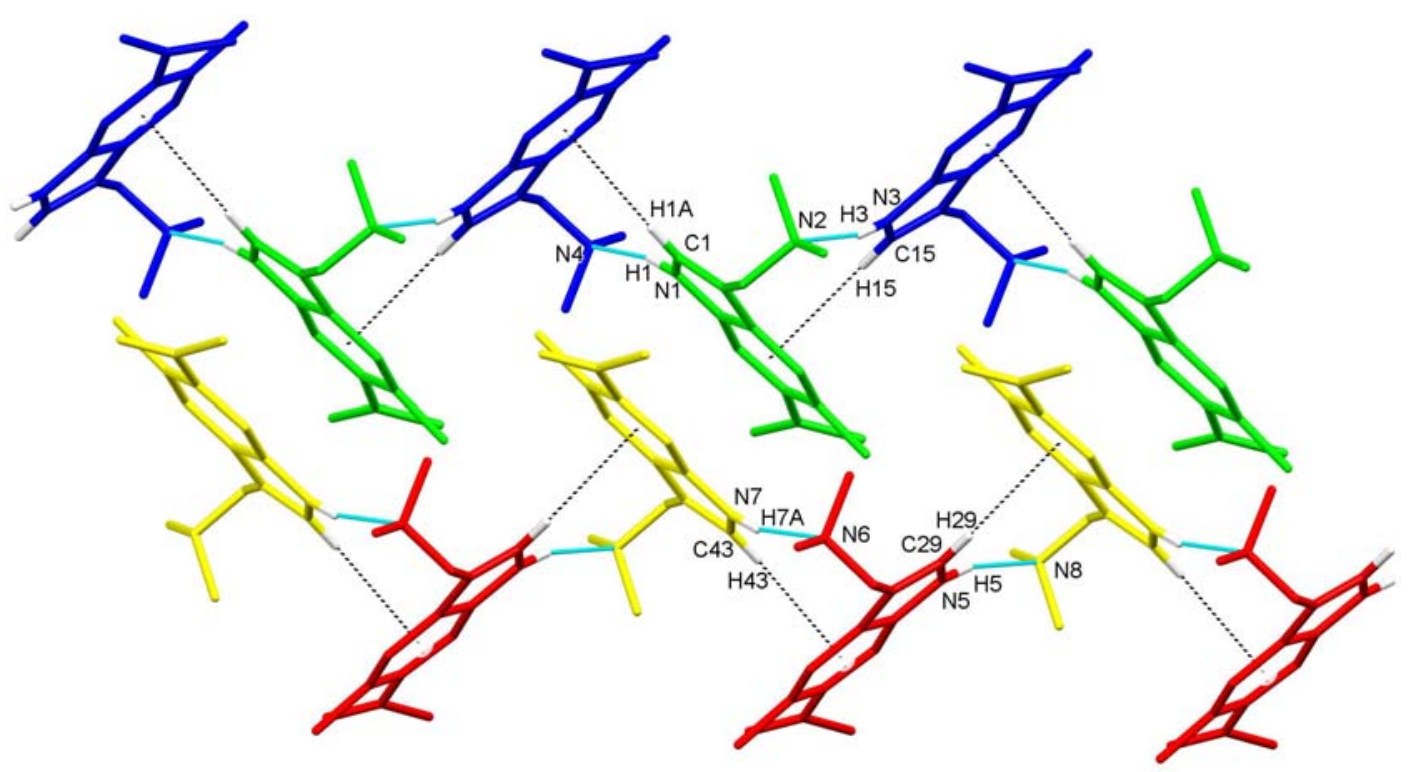

Figure 5. Formation of two chains in $\mathbf{8}$ by four unique molecules (color code: blue, green, red, yellow) generated by N1-H1 $\cdots \mathrm{N} 4, \mathrm{~N} 3-\mathrm{H} 3 \cdots \mathrm{N} 2$, $\mathrm{N} 5-\mathrm{H} 5 \cdots \mathrm{N} 8$ and $\mathrm{N} 7-\mathrm{H} 7 \mathrm{~A} \cdots \mathrm{N} 6$ hydrogen bonding (blue dashed lines) and $\mathrm{C}-\mathrm{H} \cdots \pi$ interactions (black dashed lines). Hydrogen atoms not involved in the motif shown have been omitted for clarity.

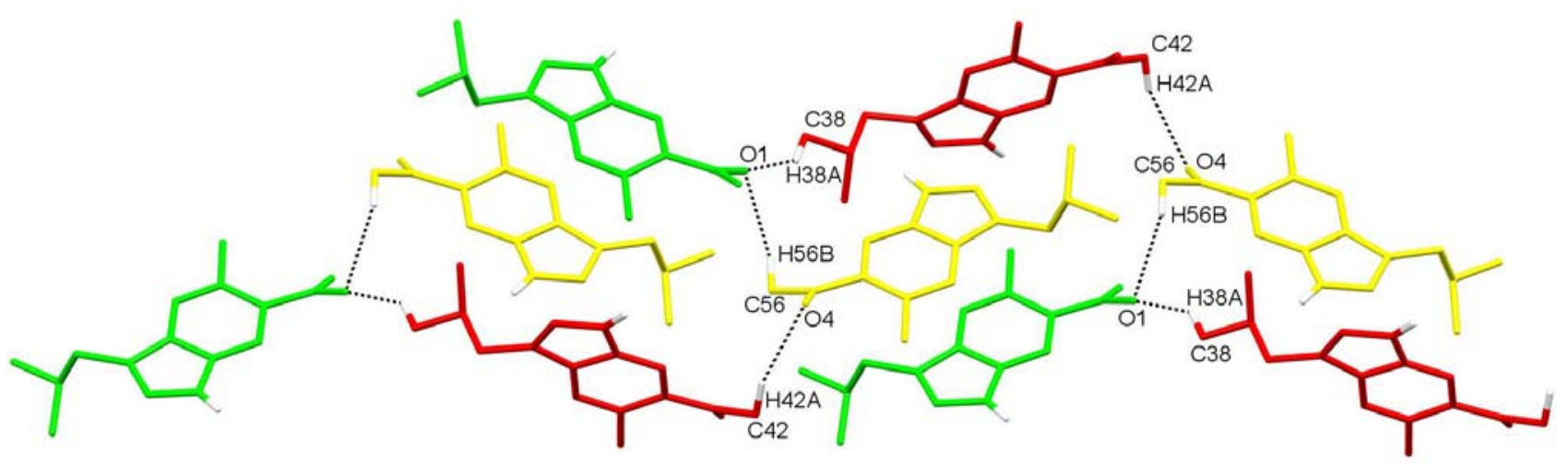

Figure 6. The arrangement of molecules of $\mathbf{8}$ formed by $\mathrm{C} 42-\mathrm{H} 42 \mathrm{~A} \cdots \mathrm{O} 4, \mathrm{C} 56-\mathrm{H} 56 \mathrm{~B} \cdots \mathrm{O} 1$ and $\mathrm{C} 38-\mathrm{H} 38 \mathrm{~A} \cdots \mathrm{O} 1$ interactions (dashed lines). Hydrogen atoms not involved in the motif shown have been omitted for clarity.

of one molecule and a six membered aromatic ring of the adjacent molecule (Table 2, Figure 5). Chains are crosslinked by weak $\mathrm{C} 42-\mathrm{H} 42 \mathrm{~A} \cdots \mathrm{O} 4(-x+1, y+1 / 2,-z+1)$ and C56-H56B $\cdots \mathrm{O} 1(-x+1, y-1 / 2,-z+1)$ hydrogen bonding between methyl group of the acetyl moiety of one molecule and the carbonyl oxygen of the adjacent molecule together with weak C38-H38A $\cdots \mathrm{O} 1(-x, y-1 / 2,-z+1)$ hydrogen bonding between one methyl group of the dimethylamino moiety of one molecule and the carbonyl oxygen of the adjacent molecule (Table 2, Figure 6). In addition, supramolecular structure $\mathbf{8}$ is stabilized by medium strong $\pi \cdots \pi$ interactions between five membered pyrrole ring ( $\mathrm{Cg} 1, \mathrm{Cg} 4, \mathrm{Cg} 7$ and $\mathrm{Cg} 10)$ of one molecule and a six membered ring $(C g 2, C g 5, C g 8$ and $C g 11)$ of the other molecule with an average centroid-to-centroid distance of $3.91 \AA$ (Figure 7). For other data regarding $\pi \cdots \pi$ interactions, see Table 3.

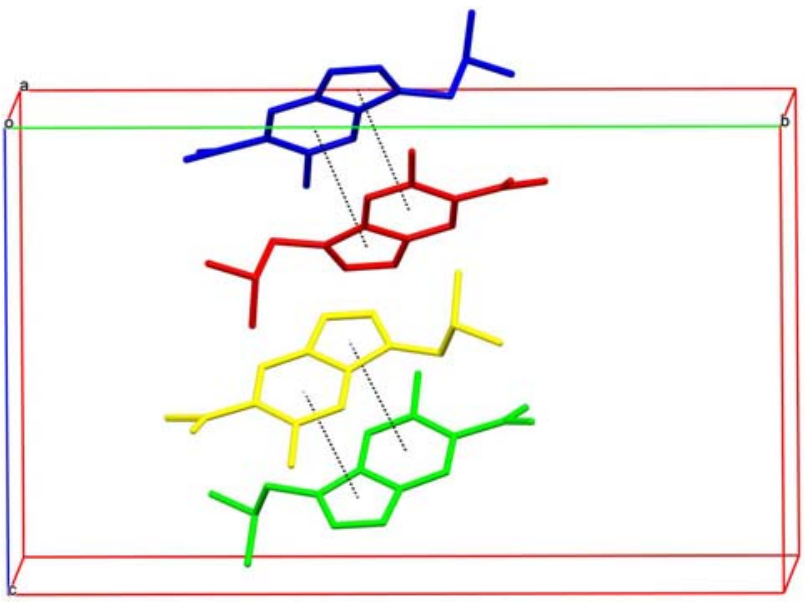

Figure 7. The formation of $\pi \cdots \pi$ interactions in $\mathbf{8}$ (dashed lines). Hydrogen atoms have been omitted for clarity. 
Table 3. $\pi \cdots \pi$ interactions in $\mathbf{8}$.

\begin{tabular}{clllrr}
\hline $\boldsymbol{C g} \cdots \boldsymbol{C g}$ & $\mathbf{C g I} \cdots \mathbf{C g J}(\AA)$ & $\boldsymbol{\alpha}\left({ }^{\circ}\right)$ & $\boldsymbol{\beta}\left(^{\circ}\right)$ & CgI-Perp $(\AA)$ & Symmetry code \\
\hline$C g 1 \cdots C g 11$ & $3.927(2)$ & $2.13(18)$ & 22.93 & $3.5573(14)$ & $x-1, y, z$ \\
$C g 2 \cdots C g 10$ & $3.9126(19)$ & $1.52(17)$ & 24.59 & $3.5600(14)$ & $x-1, y, z$ \\
$C g 4 \cdots C g 8$ & $3.908(2)$ & $2.25(18)$ & 22.39 & $-3.5523(14)$ & $x, y, z+1$ \\
$C g 5 \cdots C g 7$ & $3.9039(19)$ & $1.89(17)$ & 24.38 & $-3.5460(14)$ & $x, y, z+1$ \\
\hline
\end{tabular}

$\mathrm{CgI} \cdots \mathrm{CgJ}, \alpha, \beta$ and CgI-Perp are, respectively, the centroid-to-centroid distance between rings I and $\mathbf{J}(\AA)$, the inter-ring dihedral angle $\left({ }^{\circ}\right)$, slip angle $\left({ }^{\circ}\right)$, and the perpendicular distance of $\mathrm{CgI}$ from ring $\mathrm{J}(\AA)$. Ring centroids: $\mathrm{Cg} 1$ (N1/C1-C3/C8), Cg2 (C3-C8), Cg4 (N3/C15-C17/C22), $C g 5$ (C17-C22), Cg7 (N5/C29-C31/C36), Cg8 (C31-C36), $C g 10$ (N7/C43-C45/C50) and $C g 11$ (C45-C50).

\section{Conclusion}

With the Diels-Alder reaction between a substituted $2 H$-pyran-2-one and (Z)-1-methoxybut-1-en-3-yne as the dienophile we have prepared a cycloadduct that was in the next, one-pot domino process cyclized and deprotected into the desired 5-methyl-6-acetyl substituted indole and further derivatized via Mannich reaction to the 5-methyl6-acetylgramine. Single-crystal X-ray diffraction analysis of both compounds provided a valuable insight into their molecular structures as well as the mode of packing and crystal architecture showing that in the indole derivative the molecules are linked via $\mathrm{N}-\mathrm{H} \cdots \mathrm{O}$ hydrogen bonds between the secondary amine group and carbonyl moiety of the acetyl group of adjacent molecules, whereas the molecules of gramine are linked via $\mathrm{N}-\mathrm{H} \cdots \mathrm{N}$ hydrogen bonds between the secondary and tertiary amine groups of adjacent molecules. In both structures weak $\mathrm{C}-\mathrm{H} \cdots \mathrm{O}, \mathrm{C}-\mathrm{H} \cdots \pi$ and $\pi \cdots \pi$ interactions were also observed.

\section{Supplementary Material}

Crystallographic data of $\mathbf{1}$ and $\mathbf{2}$ were deposited in the Cambridge Crystallographic Data Center under the number CCDC 1503990-1503991. CIF files containing complete information on the studied structures may be obtained free of charge from the Director, CCDC, 12 Union Road, Cambridge, CB2 1EZ, UK, fax +44-1223-336033; e-mail: data_request@ $@$ ccdc.cam.ac.uk or from the following web site: www.ccdc.cam.ac.uk/data_request/cif.

\section{Acknowledgement}

The authors thank the Ministry of Education, Science and Sport of the Republic of Slovenia and the Slovenian Research Agency for financial support (grant Nos.
P1-0230-0103 and P1-0230-0175). This work was also partially supported with infrastructure of the EN-FIST, Center of Excellence, Ljubljana, Slovenia.

\section{References}

1. H. Matsuo, K. Taniguchi, T. Hiramoto, T. Yamada, Y. Ichinose, K. Toyoda, K. Takeda, T. Shiraishi, Plant. Cell. Physiol. 2001, 42, 1103-1111. http://dx.doi.org/10.1093/pcp/pce139

2. B. B. Semenov, V. G. Granik, Khim. Farm. Zh. 2004, 38, 3-26.

3. J. Letessier, H. Detert, K. Götz, T. Opatz, Synthesis 2012, 44, 747-754. http://dx.doi.org/10.1055/s-0031-1289675

4. T. Yamakawa, E. Ideue, Y. Iwaki, A. Sato, H. Tokuyama, J. Shimokawa, T. Fukuyama, Tetrahedron 2011, 67, 65476560. http://dx.doi.org/10.1016/j.tet.2011.05.112

5. M. Reinfelds, K. Kalinins, D. Katkevica, R. Zemribo, M. Katkevics, Tetrahedron Lett. 2015, 56, 5882-5885. http://dx.doi.org/10.1016/j.tetlet.2015.09.017

6. A. J. Keith, S. D. Kosik, L. M. V. Tillekeratne, M. R. Mason, Synlett 2014, 25, 977-982. http://dx.doi.org/10.1055/s-0033-1340846

7. Y. Wei, L. Shi, K. Wang, M. Liu, Q. Yang, Z. Yang, S. Ke, Molecules 2014, 19, 8949-8964.

http://dx.doi.org/10.3390/molecules19078949

8. M. M. Heravi, V. Zadsirjan, Z. B. Savadjani, Curr. Org. Chem. 2014, 18, 2857-2891. http://dx.doi.org/10.2174/1385272819666141014212254

9. H. G. Dai, J. T. Li, T. S. Li, Synth. Commun. 2006, 36, 18291835. http://dx.doi.org/10.1080/00397910600602503

10. S. Ke, L. Shi, X. Cao, Q. Yang, Y. Liang, Z. Yang, Eur. J. Med. Chem. 2012, 54, 248-254. http://dx.doi.org/10.1016/j.ejmech.2012.05.003

11. M. Köksal Akkoç, M. Yarım Yüksel, İ. Durmaz, R. Çetin Atalay, Turk. J. Chem. 2012, 36, 515-525.

12. K. Kranjc, M. Kočevar, Tetrahedron 2008, 64, 45-52. http://dx.doi.org/10.1016/j.tet.2007.10.099

13. Agilent, CrysAlis PRO, Agilent Technologies, Yarnton, Oxfordshire, England, 2013.

14. L. Palatinus, G. Chapuis, J. Appl. Cryst. 2007, 40, 786-790. http://dx.doi.org/10.1107/S0021889807029238

15. G. M. Sheldrick, Acta Cryst. 2015, C71, 3-8.

16. K. Kranjc, M. Kočevar, Arkivoc 2013, (i), 333-363.

17. K. Kranjc, M. Kočevar, F. Perdih, Acta Cryst. 2011, C67, o201-o205. 
18. K. Kranjc, A. Juranovič, M. Kočevar, F. Perdih, J. Chem. Crystallogr. 2012, 42, 443-449. http://dx.doi.org/10.1007/s10870-011-0266-5

19. A. Juranovič, K. Kranjc, S. Polanc, F. Perdih, M. Kočevar, Monatsh. Chem. 2012, 143, 771-777. http://dx.doi.org/10.1007/s00706-012-0734-4

20. J. Suljagić, A. Juranovič, M. Krivec, K. Kranjc, M. Kočevar, J. Heterocycl. Chem. 2016, in press, doi: 10.1002/jhet.2603. http://dx.doi.org/10.1002/jhet.2603

21. K. Kranjc, M. Kočevar, New J. Chem. 2005, 29, 1027-1034. http://dx.doi.org/10.1039/b504852d

22. V. Lanke, K. R. Prabhu, Org. Lett. 2013, 15, 2818-2821. http://dx.doi.org/10.1021/ol4011486

23. V. Kepe, M. Kočevar, S. Polanc, B. Verček, M. Tišler, Tetrahedron 1990, 46, 2081-2088. http://dx.doi.org/10.1016/S0040-4020(01)89774-X

24. V. Kepe, M. Kočevar, S. Polanc, J. Heterocycl. Chem. 1996, 33, 1707-1710. http://dx.doi.org/10.1002/jhet.5570330626

25. V. Kepe, S. Polanc, M. Kočevar, Heterocycles 1998, 48, 671-678. http://dx.doi.org/10.3987/COM-97-8048

26. F. H. Allen, O. Kennard, D. G. Watson, L. Brammer, A. G. Orpen, R. Taylor, J. Chem. Soc., Perkin Trans. II 1987, S1-S19. http://dx.doi.org/10.1039/p298700000s1

27. F. Odame, E. Hosten, R. Betz, K. Lobb, Z. R. Tshentu, Acta Chim. Slov. 2015, 62, 986-994.

http://dx.doi.org/10.17344/acsi.2015.1703
28. T. Guo, Q. Jiang, Z. Yu, Org. Chem. Front 2015, 2, 13611365. http://dx.doi.org/10.1039/C5QO00203F

29. A. Nakhi, B. Prasad, U. Reddy, R. M. Rao, S. Sandra, R. Kapavarapu, D. Rambabu, G. R. Krishna, C. M. Reddy, K. Ravada, P. Misra, J. Iqbal, M. Pal, MedChemComm 2011, 2, 1006-1010. http://dx.doi.org/10.1039/c1md00148e

30. S. N. Golubev, Y. D. Kondrashev, J. Struct. Chem. 1984, 25 , 467-470. http://dx.doi.org/10.1007/BF00749344

31. R. Jiang, X.-J. Wu, X. Zhu, X.-P. Xu, S.-J. Ji, Eur. J. Org. Chem. 2010, 5946-5950. http://dx.doi.org/10.1002/ejoc.201000994

32. A. J. Keith, S. D. Kosik, L. M. V. Tillekeratne, M. R. Mason, Synlett 2014, 25, 977-982. http://dx.doi.org/10.1055/s-0033-1340846

33. Q. Wang, Z.-Y. Fu, X. Li, L.-M. Yu, Acta Cryst. 2011, E67, o1671.

34. J. Bernstein, R. E. Davis, N. L. Shimoni, N.-L. Chang, Angew. Chem., Int. Ed. 1995, 34, 1555-1573. http://dx.doi.org/10.1002/anie.199515551

35. C. Janiak, J. Chem. Soc., Dalton Trans. 2000, 3885-3896. http://dx.doi.org/10.1039/b003010o

36. T. Dorn, C. Janiak, A.-K. Shandi, CrystEngComm 2005, 7, 633-641. http://dx.doi.org/10.1039/b508944a

37. X.-J. Yang, F. Drepper, B. Wu, W.-H. Sun, W. Haehnel, C. Janiak, Dalton Trans. 2005, 256-267.

http://dx.doi.org/10.1039/B414999H

\section{Povzetek}

Opisujemo sintezo in kristalno strukturo 1-(5-metil-1H-indol-6-il)etan-1-ona (7), $\mathrm{C}_{11} \mathrm{H}_{11} \mathrm{NO}$, in 1-\{3-[(dimetilamino)metil]-5-metil-1H-indol-6-il\}etan-1-ona (8), $\mathrm{C}_{14} \mathrm{H}_{18} \mathrm{~N}_{2} \mathrm{O}$. Sinteza temelji na Diels-Alderjevi cikloadiciji substituiranega $2 H$-piran-2-onskega derivata, ki ji sledi kislinsko katalizirana ciklizacija in oď̌čita (zadnji stopnji sta bili izvedeni kot enolončni domino proces); tako nastali indol 7 smo dalje derivatizirali z Mannichovo reakcijo do graminskega derivata 8. Strukturi 7 in $\mathbf{8}$ sta bili določeni na osnovi IR, ${ }^{1} \mathrm{H}$ NMR in masne spektroskopije, kot tudi z elementno analizo in določitvijo tališča. Z rentgensko difrakcijsko analizo monokristala smo ugotovili, da ima struktura $7 \mathrm{v}$ asimetrični enoti eno samo molekulo, struktura 8 pa štiri. Molekule so v 7 povezane z N-H… vodikovimi vezmi med sekundarno aminsko skupino ene molekule in karbonilnim delom acetilne skupine sosednje molekule. V strukturi $\mathbf{8}$ so molekule povezane preko $\mathrm{N}-\mathrm{H} \cdots \mathrm{N}$ vodikovih vezi med sekundarno aminsko skupino ene molekule in terciarno aminsko skupino sosednje molekule. Obe strukturi sta dodatno stabilizirani s šibkimi $\mathrm{C}-\mathrm{H} \cdots \mathrm{O}, \mathrm{C}-\mathrm{H} \cdots \pi$ in $\pi \cdots \pi$ interakcijami. 